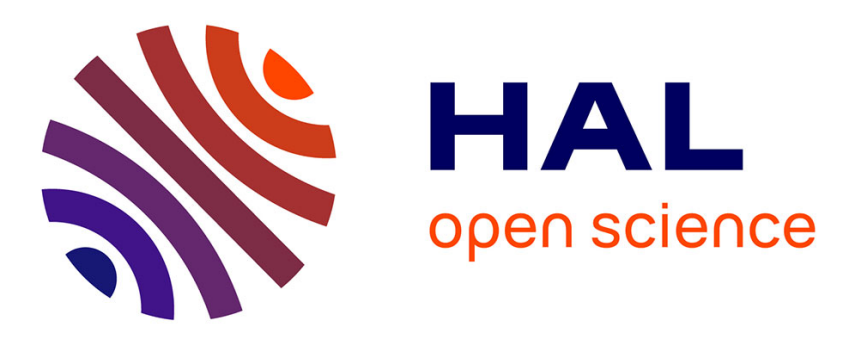

\title{
Seasonality of sulfur species (dimethyl sulfide, sulfate, and methanesulfonate) in Antarctica: Inland versus coastal regions
}

Suzanne Preunkert, Bruno Jourdain, Michel Legrand, Roberto Udisti, Silvia Becagli, Omar Cerri

\section{To cite this version:}

Suzanne Preunkert, Bruno Jourdain, Michel Legrand, Roberto Udisti, Silvia Becagli, et al.. Seasonality of sulfur species (dimethyl sulfide, sulfate, and methanesulfonate) in Antarctica: Inland versus coastal regions. Journal of Geophysical Research: Atmospheres, 2008, 113 (D15302), 1 à 10 p. 10.1029/2008JD009937 . insu-00381048

\section{HAL Id: insu-00381048 \\ https://hal-insu.archives-ouvertes.fr/insu-00381048}

Submitted on 11 Mar 2021

HAL is a multi-disciplinary open access archive for the deposit and dissemination of scientific research documents, whether they are published or not. The documents may come from teaching and research institutions in France or abroad, or from public or private research centers.
L'archive ouverte pluridisciplinaire HAL, est destinée au dépôt et à la diffusion de documents scientifiques de niveau recherche, publiés ou non, émanant des établissements d'enseignement et de recherche français ou étrangers, des laboratoires publics ou privés. 


\title{
Seasonality of sulfur species (dimethyl sulfide, sulfate, and methanesulfonate) in Antarctica: Inland versus coastal regions
}

\author{
Susanne Preunkert, ${ }^{1}$ Bruno Jourdain, ${ }^{1}$ Michel Legrand, ${ }^{1}$ Roberto Udisti, ${ }^{2}$ \\ Silvia Becagli, ${ }^{2}$ and Omar Cerri ${ }^{2}$ \\ Received 8 February 2008; revised 23 May 2008; accepted 30 May 2008; published 2 August 2008.
}

[1] To gain a better understanding of sulfate and methanesulfonate $\left(\mathrm{MS}^{-}\right)$signals recorded in central Antarctic ice cores in terms of past atmospheric changes, an atmospheric year-round study of these aerosols was performed in 2006 at the Concordia station $\left(75^{\circ} \mathrm{S}, 123^{\circ} \mathrm{E}\right)$ located on the high Antarctic plateau. In addition, a year-round study of dimethyl sulfide (DMS), the gaseous precursor of sulfur aerosol, was conducted in 2007. The DMS mixing ratio remains below 1 pptv from October to January and exhibits a maximum of $10 \mathrm{pptv}$ during the first half of winter (from April to July). Surprisingly, the well-marked maximum of sulfur aerosol recorded in January at coastal Antarctic sites is observed at Concordia for sulfate but not for $\mathrm{MS}^{-}$which peaks before and after sulfate in November and March, respectively. This first study of DMS and of its by-oxidation aerosol species conducted at inland Antarctica points out the complex coupling between transport and photochemistry of sulfur species over Antarctica. The findings highlight the complexity of the link between $\mathrm{MS}^{-}$ice core records extracted at high Antarctic plateau sites and DMS emissions from the Southern ocean.

Citation: Preunkert, S., B. Jourdain, M. Legrand, R. Udisti, S. Becagli, and O. Cerri (2008), Seasonality of sulfur species (dimethyl sulfide, sulfate, and methanesulfonate) in Antarctica: Inland versus coastal regions, J. Geophys. Res., 113, D15302,

doi:10.1029/2008JD009937.

\section{Introduction}

[2] The coupling between climate and biogeochemical cycles involves complex processes which are not yet fully elucidated. Polar ice cores provide a unique archive of climate proxies that may help to address some relevant key questions [e.g., Legrand and Mayewski, 1997]. For instance, sulfur aerosols formed from the oxidation of DMS emitted by phytoplankton plays an important role on the Earth's albedo, particularly in the Southern Hemisphere [Gondwe et al., 2003]. Since, in contrast to sulfate, $\mathrm{MS}^{-}$ is exclusively formed by photo-oxidation of DMS, its records extracted from Antarctic ice cores were used to investigate past bioproductivity of the Southern Ocean [Legrand and Feniet-Saigne, 1991; Legrand et al., 1991] and to reconstruct past sea-ice extend [Welch et al., 1993; Curran et al., 2003]. However, the interpretation of $\mathrm{MS}^{-}$ ice core records is still ambiguous due to the complex processes that control the atmospheric formation of $\mathrm{MS}^{-}$ [Davis et al., 1998] and possible post-snow-deposition losses [Wagnon et al., 1999; Weller et al., 2004]. To progress on these questions, atmospheric records of both DMS and sulfur aerosol are needed. Multiple year-round atmospheric records of sulfur aerosols (sometimes completed by DMS

\footnotetext{
${ }^{1}$ Laboratoire de Glaciologie et Géophysique de l'Environnement du Centre National de la Recherche Scientifique, St. Martin d'Hères, France.

${ }^{2}$ Department of Chemistry, University of Florence, Florence, Italy.

Copyright 2008 by the American Geophysical Union. 0148-0227/08/2008JD009937
}

data) are now available at coastal Antarctic sites [Minikin et al., 1998; Jourdain and Legrand, 2001; Preunkert et al., 2007]. Inland Antarctica year-round DMS records are not available and if existing, atmospheric records of sulfur aerosols remain mainly restricted to the austral summer [Arimoto et al., 2001, 2004; Piel et al., 2006].

[3] We here report on the first year-round record of DMS obtained in 2007 at Concordia and year-round records of $\mathrm{MS}^{-}$and sulfate obtained at the same site in 2006. The seasonal cycles of these three sulfur species are compared to the corresponding ones (2007 for DMS and 2006 for MS $^{-}$ and sulfate) obtained at the coastal site of Dumont d'Urville $\left(66^{\circ} \mathrm{S}, 140^{\circ} \mathrm{E}, \mathrm{DDU}\right)$. This comparison of key species of the sulfur cycle (precursor and final oxidation products) between coastal and inland Antarctica evidences important findings for the atmospheric meaning of the ice core record of sulfur species extracted from deep ice cores drilled at inland Antarctica.

\section{Methods}

[4] Year-round aerosol samplings were conducted in 2006 at the Concordia Station (central Antarctica, $75^{\circ} \mathrm{S}$, $123^{\circ} \mathrm{E}, 3220 \mathrm{~m}$ above sea level) located $1100 \mathrm{~km}$ away from the nearest coast. Bulk aerosol samples were collected on Gelman Zefluor ( $47 \mathrm{~mm}$ diameter, $0.5 \mu \mathrm{m}$ pore size) filters by sucking air at $2.5 \mathrm{~m}$ above the snow surface at a flow rate of $1.3 \mathrm{~m}^{3}$ STP $\left(25^{\circ} \mathrm{C}, 1013 \mathrm{hPa}\right) \mathrm{h}^{-1}$. Filter holders were prepared prior sampling under a laminar flow hood and brought to the sampling site in polyethylene bags. After 
sampling, filters were stored frozen in $20 \mathrm{~mL}$ polycarbonate vials sealed in polyethylene bags until extraction with ultrapure water/methanol solution and analysis at the laboratory in Grenoble. Forty samples were collected in 2006 between 17 January and 27 December on a weekly basis (mean sampled air volume: $215 \mathrm{~m}^{3} \mathrm{STP}$ per sample). Filter blanks were regularly obtained during this period. Blank concentrations become only significant for sodium $(0.25 \pm$ $\left.0.15 \mathrm{nmol} \mathrm{m}^{-3} \mathrm{n}=19\right)$, thus a blank correction of data was made for this species.

[5] $\mathrm{Na}^{+}, \mathrm{MS}^{-}$(i.e., $\mathrm{CH}_{3} \mathrm{SO}_{3}^{-}$), and $\mathrm{SO}_{4}^{2-}$ analysis were made by ion chromatography under working conditions summarized by Minikin et al. [1998] and Wagenbach et al. [1998]. For sulfate and $\mathrm{MS}^{-}$the uncertainty is mainly determined by the ion chromatography accuracy, which is typically $5 \%$. In the case of sodium levels below $0.2 \mathrm{nmol} \mathrm{m}^{-3}$, the uncertainty becomes larger due to the blank variability.

[6] DMS air samplings and analysis started at Concordia in December 2006 and went on until December 2007, using a similar method as deployed at DDU since December 1998 [Jourdain and Legrand, 2001; Preunkert et al., 2007]. DMS samplings were performed by pressurizing electro polished stainless steel canisters of $6 \mathrm{~L}$ up to 3 bars during a few minutes with a membrane pump (Millipore, model XX5522050). Up to 12 canisters pressurized to 3 bars were used to sample more than $100 \mathrm{~L}$ of air per sample. In general one DMS sampling was achieved and immediately analyzed each week, except from 15 March to 20 April due to a breakdown of the analyzer. Samples were analyzed using a gas chromatograph equipped with a flame photometric detector (HP6890, $393 \mathrm{~nm}$ ). Hereby DMS is cryogenically trapped at $-60^{\circ} \mathrm{C}$ on a Tenax sample loop maintained in an ethanol bath. DMS is subsequently transferred to the GC by thermal desorption of the Tenax trap in a boiling water bath (i.e., $\sim 88^{\circ} \mathrm{C}$ at 650 mbar). Detailed working conditions of the gas chromatograph are given by Legrand et al. [2001]. Weekly calibrations were made using a permeation tube (VICI Metronics, Santa Clara, California) thermostated at $30^{\circ} \mathrm{C}$. The permeation tube was calibrated against the one used at DDU. The detection limit of the gas chromatograph is close to 0.2 nanogram, leading to an atmospheric detection limit of $0.7 \mathrm{pptv}$ when $100 \mathrm{~L}$ of air were sampled, or lower when a larger air volume (up to $200 \mathrm{~L}$ ) was sampled.

\section{Seasonality of DMS: Central Versus Coastal Antarctica}

[7] In midsummer season (December 2006 to January 2007) DMS mixing ratios at Concordia remained below detection limit, except 24 January (0.5 pptv). DMS started to be detectable at the level of a few pptv in February and March (Figure 1). During the first part of winter (from end of April to July), the mixing ratio was sometimes as high as 11 pptv. During the second part of winter it gradually decreased from 4.5 pptv end of July to 1 pptv in September and below 0.5 pptv in late November.

[8] The very low DMS mixing ratios recorded at Concordia in midsummer are consistent with those obtained during the ISCAT 1998 and 2000 campaigns performed at the South Pole [Davis et al., 2004]. Here DMS was investigated by using grab sample/GC/MS. From 12 November to
31 December DMS mixing ratio remained below the detection limit of 2 pptv, reached 2.4 pptv 12 January and 7.3 pptv 1 February [Swanson et al., 2004].

[9] For the entire course of winter, the Concordia DMS record remains unique for central Antarctica. The seasonal cycle of DMS at Concordia, characterized by a summer minimum, differs from that observed at the coastal site of DDU (Figure 1). Note that DMS mixing ratios measured in summer 2007 at DDU were relatively low compared to those observed during previous summers. Such a strong interannual variability of atmospheric DMS levels at coastal Antarctic sites was found to be mainly related to interannual changes of oceanic DMS concentrations [Preunkert et al., 2007]. Considering the mean DMS mixing ratio at the two sites and given the DMS lifetime with respect to $\mathrm{OH}$ reactions of 1.2 days in January (see calculations detailed in sections 7.1 and 7.2), a transit time of 7 days for an air parcel traveling from coastal to inland Antarctica is required to drop the DMS level of 40 pptv at DDU (Figure 1) below the detection limit at Concordia. That is consistent with a typical transit time of 9 days for air masses between coastal and inland Antarctic sites [Swanson et al., 2004]. As discussed in section 7.3, the atmospheric lifetime of DMS would be even shorter ( 0.7 days) if its reaction with $\mathrm{BrO}$ is also considered. In April, the lifetime of DMS with respect to $\mathrm{OH}$ reactions becomes longer ( 6 days at the coast and 12 days over the high Antarctic plateau) and the 24 pptv of DMS observed at DDU would drop to 9 pptv at Concordia for a transit time of 9 days. Although being uncertain, these calculations clearly point out that the recovery of DMS levels at Concordia at the end of summer is related to an increase of the DMS lifetime, due to decreased oxidant levels, which counteracts the lowered DMS level over the Antarctic Ocean. Later in winter, the decreasing trend of DMS recorded at coastal Antarctica is well reflected in the Concordia record (Figure 2). In winter (from April to September), the DMS mixing ratio decrease from coastal to inland Antarctica remains close to a factor of 2.6. Such a relatively small difference in DMS levels between the marine boundary layer and the atmosphere over inland Antarctica suggests that at that time of the year, the photochemistry of DMS remains very weak. Indeed, the lifetime of DMS with respect to $\mathrm{OH}$ reactions is very long (lifetime of 60 days in May for instance), however the reaction of DMS with nitrate radical $\left(\mathrm{NO}_{3}\right)$ has to be considered at that season. To date no $\mathrm{NO}_{3}$ measurements exist from the Antarctic atmosphere. The only available information is that the $\mathrm{NO}_{3}$ mixing ratio remains below 2 pptv at coastal Antarctica even in winter [Jones et al., 2007]. The IMAGE transport-chemistry model simulates a maximum mixing ratio of $\mathrm{NO}_{3}$ of 0.06 pptv at DDU in July [Pham et al., 1995]. The rate constant of the reaction between DMS and $\mathrm{NO}_{3}\left(1.8 \times 10^{-12} \mathrm{~cm}^{3}\right.$ molecule ${ }^{-1} \mathrm{~s}^{-1}$ at $230 \mathrm{~K}$, http://www.iupac-kinetic.ch.cam.ac.uk/) would lead to a lifetime of DMS of 4 days in July. Thus, DMS data from DDU and Concordia tend to suggest that a $\mathrm{NO}_{3}$ mixing ratio of $0.06 \mathrm{pptv}$ over Antarctica in winter represents an upper limit. Note also that a DMS lifetime of at least a few days in winter would suggest a rather low level of $\operatorname{BrO}\left(2 \times 10^{6}\right.$ molecule $\mathrm{cm}^{-3}$, i.e., less than $0.1 \mathrm{pptv}$, for a lifetime of 4 days). Such a low $\mathrm{BrO}$ mixing ratio in 
DDU

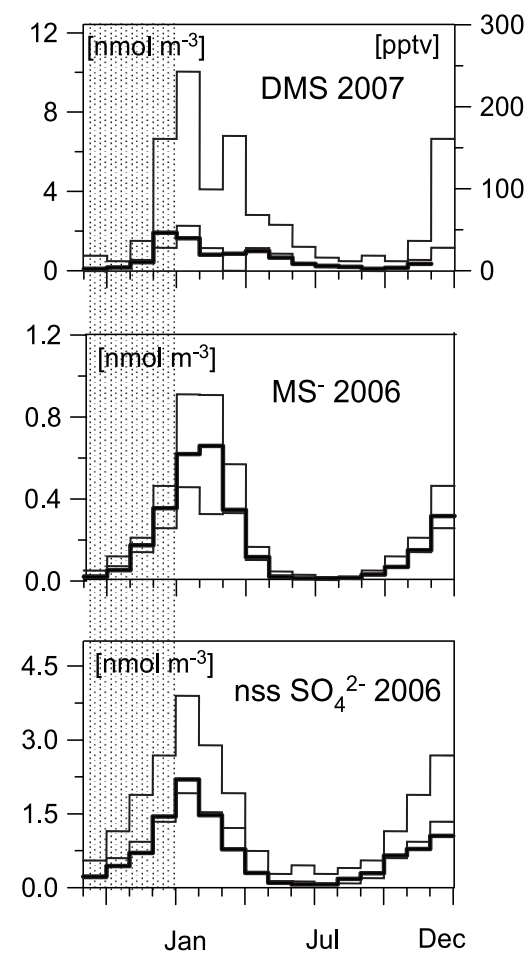

Concordia
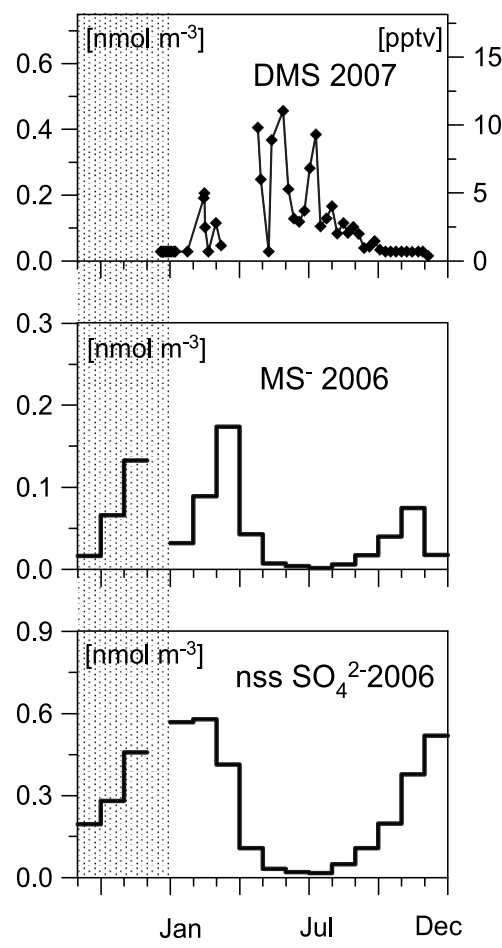

Figure 1. Monthly mean mixing ratios of DMS in 2007 and concentrations of aerosols $\left(\mathrm{MS}^{-}\right.$, and $\mathrm{nsSSO}_{4}^{2-}$ ) in 2006 at Concordia (right) and Dumont D'Urville (DDU, left). For the DDU records the thin lines indicate the interannual variability of monthly means (mean \pm the standard deviation) over 19992006. Grey areas refer to end of 2006 for DMS and end of 2005 for aerosols.

midwinter is consistent with observations made at coastal Antarctica (see section 7.1).

\section{Seasonality of Sulfur Aerosols in Central Antarctica}

[10] The sodium level observed at Concordia remains generally low $\left(0.5 \mathrm{nmol} \mathrm{m}^{-3}\right.$ in winter and less in summer) except the end of September (Figure 2). Although being weak, the sea-salt contribution to sulfate was here considered. The study of the size-segregated composition of aerosol conducted in 2006 at Concordia has shown that sea-salt aerosol is there depleted in sulfate relative to sodium in winter (mean mass sulfate to sodium ratio of 0.11 over midwinter, dropping to 0.07 in September, instead of 0.25 in seawater) [Jourdain et al., 2008]. These sulfate to sodium ratio values were used to calculate $\mathrm{nssSO}_{4}^{2-}$ levels. As discussed by the authors, the sulfate to sodium ratio of 0.11 derived for midwinter conditions has still to be considered carefully. Anyway, for a mean midwinter sulfate level of $0.056 \mathrm{nmol} \mathrm{m} \mathrm{m}^{-3}$, the sea-salt contribution remains weak $\left(510^{-3} \mathrm{nmol} \mathrm{m}^{-3}\right.$ and $0.01 \mathrm{nmol} \mathrm{m}^{-3}$ by considering a sulfate to sodium mass ratio of 0.11 and 0.25 in sea-salt aerosol, respectively). Concentrations of $\mathrm{nssSO}_{4}^{2-}$ exhibit a minimum of $0.02 \mathrm{nmol} \mathrm{m}^{-3}$ in July, gradually increase in spring and

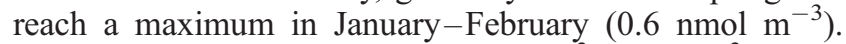
Though being also minima in July $\left(10^{-3} \mathrm{nmol} \mathrm{m}^{-3}\right), \mathrm{MS}^{-}$ concentrations show a first increase from September to November, a sharp decrease in December-January, and a reincrease with a maximum of $0.17 \mathrm{nmol} \mathrm{m}^{-3}$ in March. As a consequence, the $\mathrm{MS}^{-}$to $\mathrm{nssSO}_{4}^{2-}$ mass ratio (r) exhibits a first peak in November (20\%) and a far more pronounced one in March-April (40\%) whereas it remains relatively low $(10 \%)$ in December and January (Figure 2).

[11] Most of simultaneous $\mathrm{MS}^{-}$and $\mathrm{nssSO}_{4}^{2-}$ studies achieved until now at inland Antarctic sites cover only the summer period (i.e., November to January, see Table 1). However, they also indicate relatively low $\mathrm{MS}^{-}$values with respect to those of $\mathrm{nssSO}_{4}^{2-}$, resulting in $\mathrm{r}$ values ranging from 3 to $20 \%$. The unique year-round study of sulfur aerosols previously conducted over inland Antarctica was the recent one from Weller and Wagenbach [2007] at the Kohnen station $\left(75^{\circ} \mathrm{S}, 0^{\circ} \mathrm{E}\right)$. The low $\mathrm{r}$ values obtained here in December $(8 \%)$ in contrast to higher ones measured in November (12\%) and March (37\%) show that the striking seasonal feature of $\mathrm{r}$ is also recorded at this site, although less pronounced than at Concordia.

\section{Sulfur Aerosols at Coastal and Central Antarctica}

[12] Atmospheric levels of $\mathrm{MS}^{-}$and $\mathrm{nssSO}_{4}^{2-}$ at the coastal Antarctic sites of DDU, Neumayer $\left(70^{\circ} \mathrm{S}, 8^{\circ} \mathrm{W}\right)$ and Halley $\left(75^{\circ} \mathrm{S}, 26^{\circ} \mathrm{W}\right)$ were already discussed by Minikin et al. [1998] who concluded that the strong maxima seen at all sites in January are driven by the summer recovery of a dominant marine biogenic sulfur source (DMS) which follows the sea-ice retreat. Since that time the year-round DDU aerosol record has been extended in the framework of the French environmental observation service CESOA (Etude 


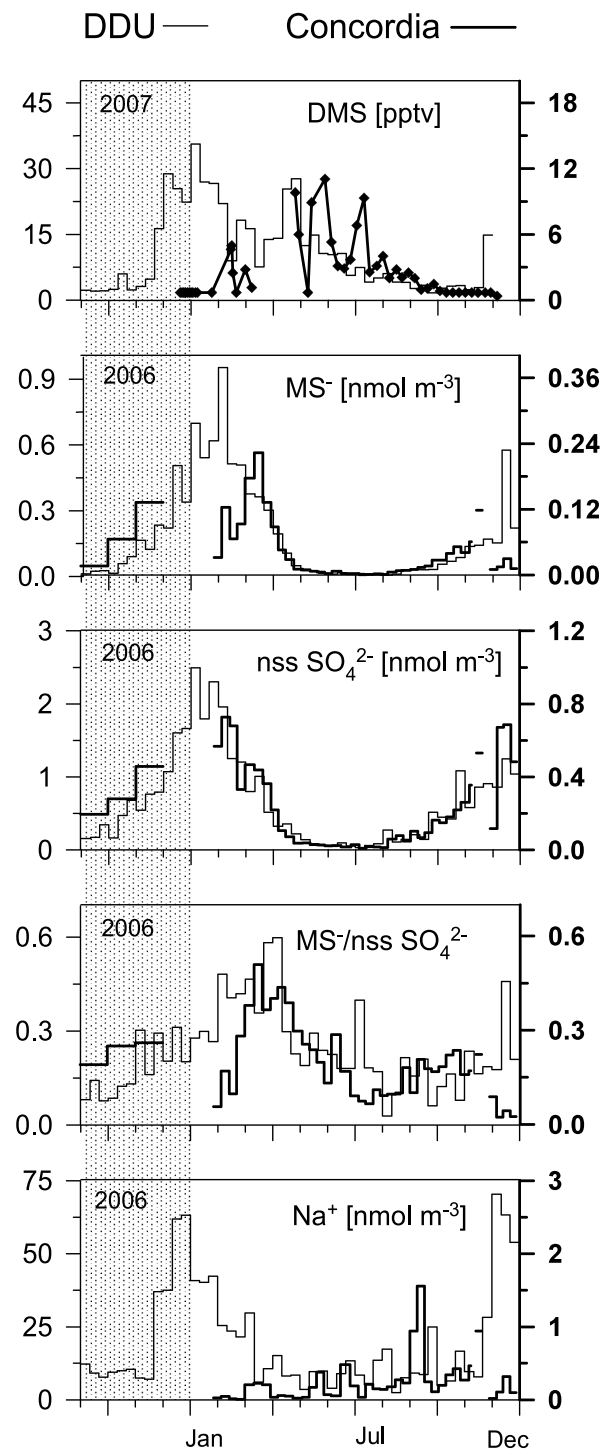

Figure 2. Comparison of DMS mixing ratio (from end of 2006 to 2007), $\mathrm{MS}^{-}$and $\mathrm{nssSO}_{4}^{2-}$ concentrations, $\mathrm{MS}^{-} /$ nssSO ${ }_{4}^{2-}$ mass ratio, and $\mathrm{Na}^{+}$concentrations (from end of 2005 to 2006) at DDU (thin lines) and Concordia (thick lines). du cycle atmosphérique du Soufre en relation avec le climat aux moyennes et hautes latitudes Sud, http://cesoa.ore.fr) dedicated to the study of the sulfur cycle at middle and high southern latitudes, and covers now the 1991-2006 period (Figure 1). Consistently with data previously presented by Jourdain and Legrand [2002] over 1991-2001 years and Preunkert et al. [2007] over 1999-2003 years, a well-marked summer maxima is recorded for both $\mathrm{MS}^{-}$and $\mathrm{nsSSO}_{4}^{2-}$. Mean winter minima (May-September) of $0.02 \pm$ $0.01 \mathrm{nmol} \mathrm{m}^{-3}$ for $\mathrm{MS}^{-}$, and $0.25 \pm 0.12 \mathrm{nmol} \mathrm{m}^{-3}$ for $\mathrm{nsSSO}_{4}^{2-}$ are observed, while the summer maximum in January ranges from 1.9 to $3.9 \mathrm{nmol} \mathrm{m}^{-3}$ for $\mathrm{nssSO}_{4}^{2-}$ and from 0.45 to $0.9 \mathrm{nmol} \mathrm{m}^{-3}$ for $\mathrm{MS}^{-}$, respectively.

[13] For winter months (from April to September), the decrease of concentrations between coastal to inland Antarctica is of a factor of 2.6 for $\mathrm{nsSSO}_{4}^{2-}$, and 2.9 for $\mathrm{MS}^{-}$. $\mathrm{MS}^{-}$and $\mathrm{nssSO}_{4}^{2-}$ are both present in submicrometer particles (diameters ranging between 0.1 and $0.5 \mu \mathrm{m}$ ) at coastal sites [Jourdain and Legrand, 2002] as well as at Concordia [Jourdain et al., 2008]. Harder et al. [2000] estimated the lifetime of nssSO ${ }_{4}^{2-}$ aerosol to be higher than 12 days at the South Pole in summer. The drier winter conditions would reduce aerosol wet deposition and lead to an even longer lifetime of the nssSO ${ }_{4}^{2-}$ aerosol. Therefore, the decreasing factors of sulfur aerosol levels between coastal and inland Antarctica in winter would be mainly controlled by the degree of dilution of air masses advected from the coast reaching Concordia. Note that the large decrease of sodium (a factor of 25, Figure 2) seen between coastal and inland Antarctica is due to the large contribution ( 80 to $90 \%$ of the total mass) of supermicron sea-salt particles at coastal sites [Jourdain and Legrand, 2002] resulting in a shorter atmospheric lifetime. If only the submicron fraction of sodium observed at DDU is considered (i.e., the total mass divided by a factor of 5 to 10 ), the decreasing factor of sodium levels between DDU and Concordia becomes closer (a factor of 3 to 6) to those found for $\mathrm{MS}^{-}$and $\mathrm{nsSOO}_{4}^{2-}$.

[14] If we consider the spring-summer-fall period, we can observe (Figure 2) that in spring (September-November) and fall (March-April) nssSO ${ }_{4}^{2-}$ and $\mathrm{MS}^{-}$values at Concordia station are still approximately 2.5 to 3 times lower than those at DDU. In mid summer (December to February) however, a very different pattern appears. While

Table 1. Summary of Mean nssSO ${ }_{4}^{2-}$ and $\mathrm{MS}^{-}$Concentrations and $\mathrm{MS}^{-} / \mathrm{nssSO}_{4}^{2-}$ Mass Ratio Observed in Summer at Various Inland Antarctic Sites

\begin{tabular}{|c|c|c|c|c|c|}
\hline Site & $\begin{array}{l}\mathrm{MS}^{-}, \\
\mathrm{nmol} \mathrm{m}^{-3}\end{array}$ & $\begin{array}{l}\mathrm{nssSO}_{4}^{2-} \\
\mathrm{nmol} \mathrm{m}^{-3}\end{array}$ & $\begin{array}{c}\mathrm{MS}^{-} / \mathrm{nssSO}_{4}^{2-} \\
\text { (Mass Ratio) }\end{array}$ & Month & Reference \\
\hline \multirow[t]{2}{*}{ South Pole } & 0.05 & 1.0 & 0.08 & Nov $2000 /$ Jan 2001 & Arimoto et al. [2004] \\
\hline & 0.1 & 2.2 & 0.06 & Dec 1998/Jan 1999 & Arimoto et al. [2001] \\
\hline $\begin{array}{l}\text { East Antarctic Plateau } \\
\left(78^{\circ} \mathrm{S}, 139^{\circ} \mathrm{E}\right)\end{array}$ & 0.2 & 0.9 & 0.19 & Dec 1990/Jan 1991 & de Mora et al. [1997] \\
\hline \multirow[t]{3}{*}{$\operatorname{EDML}\left(75^{\circ} \mathrm{S}, 0^{\circ} \mathrm{E}\right)$} & 0.6 & 3.7 & 0.16 & Jan/Feb 2000 & Piel et al. [2006] \\
\hline & 0.2 & 1.7 & 0.10 & Jan/Feb 2001 & \\
\hline & 0.8 & 3.3 & 0.20 & Jan/Feb 2002 & \\
\hline \multirow{6}{*}{ Concordia $\left(75^{\circ} \mathrm{S}, 123^{\circ} \mathrm{E}\right)$} & 0.03 & 1.1 & 0.03 & Dec $2000 /$ Jan 2001 & Udisti et al. [2004] \\
\hline & 0.3 & 2.6 & 0.09 & Jan 2000 & Piel et al. [2006] \\
\hline & 0.07 & 1.5 & 0.05 & Dec 2000/Jan 2001 & \\
\hline & 0.48 & 3.2 & 0.15 & Dec $2001 / \operatorname{Jan} 2002$ & \\
\hline & 0.06 & 0.6 & 0.15 & Jan/Feb 2006 & this work \\
\hline & 0.02 & 0.5 & 0.04 & Dec 2006 & \\
\hline
\end{tabular}


Table 2. Rate Coefficients of Gaseous (in $\mathrm{cm}^{3}$ molecule $\mathrm{e}^{-1} \mathrm{~s}^{-1}$ ) and Aqueous (in $\mathrm{M}^{-1} \mathrm{~s}^{-1}$ ) Phase Reactions and Branching Ratio Used in the Simple 0-D Box Model Calculations Discussed in Section $7^{\text {a }}$

\begin{tabular}{|c|c|c|}
\hline Reaction & Rate Constant and Branching Ratios & References \\
\hline $\mathrm{DMS}+\mathrm{OH}$ & $\mathrm{K}_{1}=1.1210^{-11} \mathrm{e}^{-250 / \mathrm{T}}$ & http://www.iupac-kinetic.ch.cam.ac.uk/ \\
\hline $\mathrm{DMS}+\mathrm{OH}$ & $\mathrm{K}_{2}=\left(9.510^{-39}\left[\mathrm{O}_{2}\right] \mathrm{e}^{5270 / \mathrm{T}}\right) /\left(1+7.510^{-29}\left[\mathrm{O}_{2}\right] \mathrm{e}^{5610 / \mathrm{T}}\right)$ & http://www.iupac-kinetic.ch.cam.ac.uk/ \\
\hline $\mathrm{DMS}+\mathrm{BrO}$ & $\mathrm{K}_{6}=1.5 \times 10^{-14} \mathrm{e}^{\mathrm{1000/T}}$ & http://www.iupac-kinetic.ch.cam.ac.uk/ \\
\hline $\mathrm{DMSO}+\mathrm{OH}$ & $\mathrm{K}_{3}=6.110^{-12} \mathrm{e}^{800 / \mathrm{T}}$ & http://jpldataeval.jpl.nasa.gov/ \\
\hline $\mathrm{SO}_{2}+\mathrm{OH}$ & $\begin{aligned} \mathrm{K}_{4}= & \left(\mathrm{K}_{0} /\left(1+\mathrm{K}_{0} / \mathrm{K}_{\text {inf }}\right)\right) 0.525^{[(1+\log (\mathrm{K} 0 / \mathrm{Kinf})) 2]-1} \\
& \text { with } \mathrm{K}_{0}=4.510^{-31}[\mathrm{M}](300 / \mathrm{T})^{3.9} \\
& \mathrm{~K}_{\text {inf }}=1.310^{-12}(300 / \mathrm{T})^{0.7}\end{aligned}$ & http://www.iupac-kinetic.ch.cam.ac.uk/ \\
\hline$\left(\mathrm{HSO}_{3}^{-}+\mathrm{O}_{3}\right)_{\mathrm{aq}}$ & $\mathrm{K}_{5(\mathrm{aq})}=3.710^{5} \mathrm{e}^{-5530(1 / \mathrm{T}-1 / 298)}$ & [Seinfeld and Pandis, 1998] \\
\hline$\left(\mathrm{MS}^{-}+\mathrm{OH}\right)_{\mathrm{aq}}$ & $8.810^{10} \mathrm{e}^{-2030 / 1}$ & [Zhu et al., 2003] \\
\hline$\beta_{1}$ & 1 & http://www.iupac-kinetic.ch.cam.ac.uk/ \\
\hline$\beta_{2}$ & 0 & http://www.iupac-kinetic.ch.cam.ac.uk/ \\
\hline$\beta_{3}$ & $1+0.0123(\mathrm{~T}-320)\left(\beta_{3}=0\right.$ for $\left.\mathrm{T}<239 \mathrm{~K}\right)$ & estimated from [Arsene et al., 1999] \\
\hline$\beta_{4}$ & $-0.0123(\mathrm{~T}-320)\left(\beta_{4}=0\right.$ for $\left.\mathrm{T}>320 \mathrm{~K}\right)$ & estimated from [Arsene et al., 1999] \\
\hline
\end{tabular}

$\mathrm{nssSO}_{4}^{2-}$ levels show similar temporal patterns at DDU and Concordia with by a factor of 2.5 lower values at Concordia than at DDU, $\mathrm{MS}^{-}$levels at Concordia fall by a factor of 5 with respect to those in spring and fall, whereas DDU $\mathrm{MS}^{-}$concentrations continue to increase from spring to summer to become maxima in January and February.

[15] The decrease of $\mathrm{MS}^{-}$at Concordia during midsummer conditions could be related to its photochemical destruction either during inland long-range transport or at the Concordia site. In the aqueous phase, $\mathrm{MS}^{-}$is indeed oxidized into sulfate by $\mathrm{OH}$ radicals (rate constant of $8.8 \times 10^{10} \mathrm{e}^{-2630 / \mathrm{T}}$ $\mathrm{M} \mathrm{s}^{-1}$, Table 2). As discussed by Herrmann et al. [2000], $\mathrm{OH}$ present in the aqueous phase in marine area mainly comes from the transfer of $\mathrm{OH}$ from the gas phase. Barnes et al. [2006] suggested a typical $\mathrm{OH}$ aqueous phase concentration of $6 \times 10^{-13} \mathrm{M}$ in marine area at a global scale (corresponding to a typical gas phase $\mathrm{OH}$ concentration of $10^{6}$ radicals $\mathrm{cm}^{-3}$ ). They estimated a lifetime of $\mathrm{MS}^{-}$at $295 \mathrm{~K}$ as long as 14 days, assuming that the aerosol spends a typical time of $3 \mathrm{~h}$ per day in cloud droplets in the marine boundary layer [Katoshevski et al., 1999]. The same calculation done for a transport over inland Antarctica by applying conditions (temperature, $\mathrm{OH}$ radical level) discussed in section 7.1, leads to a $\mathrm{MS}^{-}$lifetime of more than 200 days with respect to the $\mathrm{OH}$ aqueous reaction. Considering the high oxidant levels persisting at Concordia during the presence of a shallow inversion layer (see section 7.3) and assuming that the aerosol spends $24 \mathrm{~h}$ per day in liquid water droplets, the calculated lifetime of $\mathrm{MS}^{-}$drops to 4 days. Given however the scarce presence of clouds over inland Antarctica, we can rule out that the observed decrease of $\mathrm{MS}^{-}$ in January at Concordia is related to its aqueous phase oxidation into sulfate.

[16] The level of sulfur aerosols present in air masses reaching inland Antarctica would be dependent on the history of these air masses and on the chemistry they have experienced during their travel from oceanic regions toward the high Antarctic plateau. An air mass in contact with the marine boundary layer will be filled with aerosols already formed in this layer. Leaving the marine boundary layer, the air mass will then be mixed in the atmospheric layer located above the marine boundary layer, named "buffer layer" by Davis et al. [1998]. Finally, during its travel further inland, the air mass will experience free troposphere Antarctic conditions. A possible explanation for the unexpected change of $\mathrm{MS}^{-}$ compared to $\mathrm{nssSO}_{4}^{2-}$ from equinoxes to mid summer at Concordia, could be linked to a weaker contribution of air masses advected from the marine boundary layer and the buffer layer in summer with respect to the equinoxes. Indeed, in March and November at Concordia, sea-salt levels are five to ten times higher than during the summer months. If correct, we have to question why the nssSO ${ }_{4}^{2-}$ levels do not follow the decreasing trend of $\mathrm{MS}^{-}$. One reason could be due to the fact that the $\mathrm{nssSO}_{4}^{2-}$ decrease resulting from the decreased strength of marine advection is counteracted by a large presence of sulfate (and not of $\mathrm{MS}^{-}$) in the buffer layer and/or in the free Antarctic troposphere during summer. In the two next sections, we will discuss whether this scenario is realistic, examining backward trajectory analysis and doing simple 0 -D box model calculations.

\section{A Weakening Impact of Marine Advection in Summer}

[17] To characterize air masses arriving at Concordia 12day backward trajectories were computed by the HYSPLIT (Hybrid Single-Particle Lagrangian Integrated Trajectory) model (R. R. Draxler and G. D. Rolph, NOAA Air Resources Laboratory, Silver Spring, Maryland, 2003, available at http://www.arl.noaa.gov/ready/hysplit4.html) four times per day for two periods. 26 January to 2 February and 11-18 March 2006 were chosen because of the distinct $\mathrm{MS}^{-}$and sodium levels observed during these two time intervals. Back trajectories starting points were set to be 20 and $270 \mathrm{~m}$ above Concordia ground (i.e., 3250, and $3500 \mathrm{~m}$ above sea level). An isentropic vertical motion calculation method was applied to a reanalyzed meteorological data set.

[18] Typical back trajectories obtained for the two periods are illustrated in Figure 3. For the 26 January to 2 February time period, trajectories indicate that air masses reaching Concordia had only sparse contact with near surface oceanic area. During $43 \%$ of time, air masses spent more than 12 days over the Antarctic continent. When air masses had passed over the ocean, they had generally traveled at elevations higher than $3000 \mathrm{~m}$ asl. In total, only $15 \%$ of air masses arriving at Concordia from 26 January to 2 February were in contact (i.e., $<1500 \mathrm{~m}$ asl) with oceanic regions for more than 


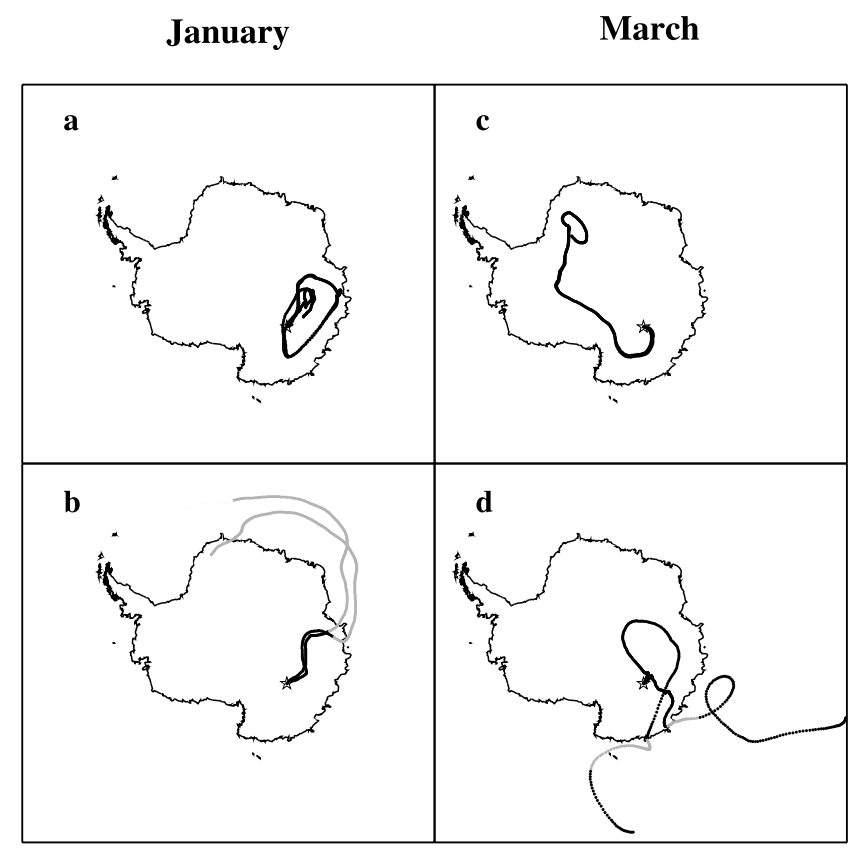

Figure 3. Typical 12 day backward trajectories from (a and b) 26 January to 2 February and (c and d) 11 to 18 March. Whereas Figures $3 \mathrm{a}$ and $3 \mathrm{c}$ refer to conditions in which the air masses remained over the Antarctic continent, Figures $3 \mathrm{~b}$ and $3 \mathrm{~d}$ show typical air masses coming from oceanic regions. Black lines indicate a traveling height below $1500 \mathrm{~m}$ asl, and gray lines indicate a height above $1500 \mathrm{~m}$ asl, respectively.

$12 \mathrm{~h}$, at least 11 days before, and for $6 \%$ of them the contact had occurred at latitudes higher than $60^{\circ} \mathrm{S}$.

[19] For the 11-18 March period, again most of time (50\%) air masses reaching Concordia had spent 12 days over the Antarctic continent. However, during this time period, air masses which had passed over the ocean had traveled at much lower elevations than in January (Figure 3). Summed up over the whole period, in $42 \%$ of cases air masses were in contact with the open ocean $(<1500 \mathrm{~m}$ asl $)$ for more than $12 \mathrm{~h}$.

[20] With that, backward trajectories indicate a total frequency of significant contact with oceanic area 3 times higher during the March period than during the January period. That is qualitatively in agreement with the larger levels of $\mathrm{MS}^{-}$and sodium recorded in March than in January at Concordia. This conclusion was found to remain valid for 2005, pointing out the overall character of the weaker frequency of contact with oceanic area of air masses reaching Concordia in January with respect to March.

\section{Sulfur Chemistry in the Buffer Layer and Above it in January and March}

[21] As discussed in section 3, due to its long atmospheric lifetime, DMS survives in winter during its transport from coastal to inland Antarctica. In contrast, the observed very low DMS levels at Concordia in summer clearly suggested that it is not the case during this season. As discussed by Davis et al. [1998], when frontal systems travel over the
Antarctic ocean, rapid vertical motions bring DMS (a not very water soluble gas) from the marine boundary layer to the buffer layer which will be subsequently oxidized. Davis et al. [1998] estimated that at the coastal Antarctic site of Palmer the temporal slice between two injections of DMS in the buffer layer would be typically 6 days. Thus the buffer layer would be periodically refilled with DMS. In the following we investigate the chemical composition of the buffer layer in March and January after a DMS injection.

\subsection{Various Oxidants of DMS in Antarctica}

[22] The most efficient atmospheric oxidants of DMS are $\mathrm{OH}, \mathrm{BrO}$, and $\mathrm{NO}_{3}$ whereas others like $\mathrm{Cl}, \mathrm{IO}$, and $\mathrm{O}_{3}$ are less efficient (see Barnes et al. [2006] for a review). Model simulations and measurements of $\mathrm{OH}$ are available for coastal Antarctica. At the coastal Antarctic site of Palmer, $\mathrm{OH}$ concentrations ranging from 1 to $2 \times 10^{5}$ radicals $\mathrm{cm}^{-3}$ were observed in summer [Jefferson et al., 1998]. At Halley measurements indicate a mean $\mathrm{OH}$ concentration of $4 \times$ $10^{5}$ radicals $\mathrm{cm}^{-3}$ [Bloss et al., 2007]. At DDU no measurements are available but concentrations simulated by the IMAGE model for January are close to $2 \times$ $10^{5}$ radicals $\mathrm{cm}^{-3}$ [Pham et al., 1995]. As discussed by Davis et al. [1998], OH concentrations would be typically twice in the buffer layer than in the boundary layer following the enhancement of UV, ozone, and NO levels.

[23] It was recently shown by Davis et al. [2004] that the photolysis of nitric acid present in surface snow layers is responsible for the high NO levels (a few hundreds of pptv) observed in the central Antarctic atmospheric boundary layer in summer. However, the $24 \mathrm{~h}$ sunlight would not permit significant levels of $\mathrm{NO}_{3}$ due to its fast photolysis.

[24] BrO mixing ratios have recently been measured over 1 year by Saiz-Lopez et al. [2007] in the coastal Antarctic boundary layer at Halley. $\mathrm{BrO}$ mixing ratios exhibit a maximum of 7 pptv in October, a mean level of 3 pptv during January-March, and drop well below 1 pptv between May and August. As discussed by Read et al. [2008] such high summer BrO levels make the BrO reaction on DMS producing DMSO faster that the one with $\mathrm{OH}$. However, it is still difficult to conclude in what extent this finding remains true at other Antarctic sites. Indeed Wagner et al. [2007] showed that the level of BrO, which has a lifetime of a few hours in the marine boundary layer, depends strongly on the contact time the air mass had with sea-ice. Since there is far less sea-ice in the Indian Ocean sector facing DDU than in the

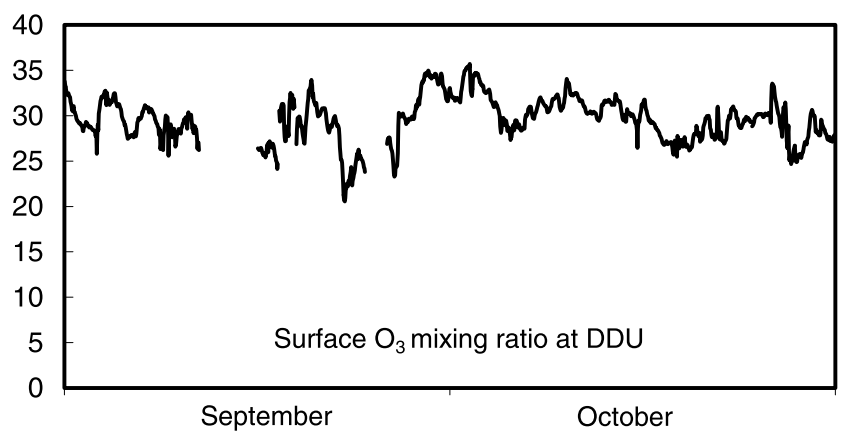

Figure 4. Surface ozone mixing ratio (in ppbv) observed at DDU in September and October 2007 (hourly means). 


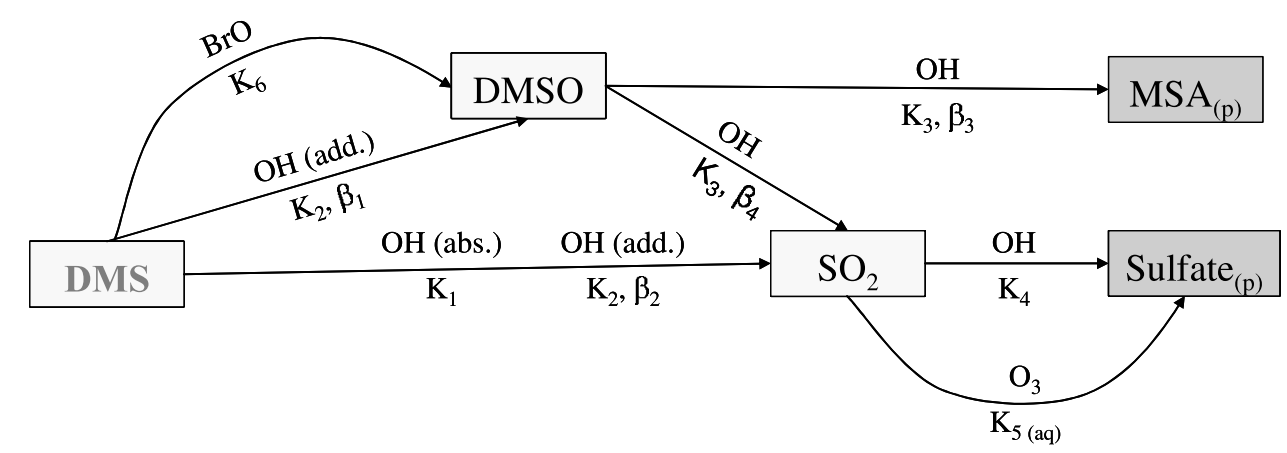

Figure 5. Simplified OH-DMS oxidation scheme for the buffer layer used in the photochemical calculations presented in section 7 .

Atlantic one facing Halley and Neumayer, lower BrO levels are expected in the marine boundary layer of the Indian sector. This difference between the two sites is highlighted in Figure 4, since the usual ozone depletion events, characterized by sudden drops of the ozone mixing ratio from 30 to 5 ppbv related to $\mathrm{BrO}$ events at Neumayer in October $[$ Frie $\beta$ et al., 2004], are not detected at DDU. In summer the sea-ice is quasi absent in the oceanic sector facing DDU, whereas the distance between the sea-ice edge and the Halley site is still as high as $600 \mathrm{~km}$ in January. Thus we may expect far lower $\mathrm{BrO}$ mixing ratios in the marine boundary layer in summer at DDU than the 3 pptv measured at Halley. Following Simpson et al. [2007], rapid vertical transport can bring rich $\mathrm{BrO}$ air mass boundary layer parcels toward the free troposphere which may contribute to the mean $\mathrm{BrO}$ mixing ratio of $1 \mathrm{pptv}$ as derived from satellite data for the free troposphere outside polar regions. This value was used as an upper limit in our calculations to evaluate the impact of $\mathrm{BrO}$ on the summer-time photochemistry of DMS in the buffer layer.

\subsection{Calculations}

[25] A simplified 0-D box model, based on Davis et al. [1998] (see Figure 5) had been used to examine the $\mathrm{OH}$ chemistry acting in the buffer layer at the scale of a few days. A typical concentration of $\mathrm{OH}$ of $4 \times 10^{5}$ radicals $\mathrm{cm}^{-3}$ and $1.5 \times 10^{5}$ radicals $\mathrm{cm}^{-3}$ (i.e., twice the value simulated by the IMAGE model for the boundary layer at DDU) was here assumed for January and March, respectively. After these calculations a sensitivity test was done to evaluate the possible role of $\mathrm{BrO}$ assuming a mixing ratio of 1 pptv $\left(2.5 \times 10^{7}\right.$ molecules $\left.\mathrm{cm}^{-3}\right)$ both in January and March. As reported in Figure 5, DMS is oxidized by $\mathrm{OH}$ radicals in both addition and abstraction pathways. Details of kinetic rates and branching ratios used in the calculations are summarized in Table 2. As depicted in Figure 5, the $\mathrm{OH}$ abstraction pathway forms $\mathrm{SO}_{2}$ only, whereas the addition pathway produces dimethyl sulfoxide (DMSO) and $\mathrm{SO}_{2}$. DMSO is further oxidized by $\mathrm{OH}$ either in the gas phase or in the aqueous or aerosol phase. A few field studies have suggested [Sciare et al., 2000; Jefferson et al., 1998] and finally shown [Legrand et al., 2001] that the heterogeneous DMSO oxidation produces efficiently $\mathrm{MS}^{-}$in the marine boundary layer. The efficiency of this process has been confirmed by kinetic studies [Bardouki et al., 2002]. The marine boundary layer experiences quite often cloud events that would render this process far more efficient than the gas phase oxidation of DMSO. As discussed by Barnes et al. [2006], even considering an absence of cloud and a very low liquid water content present on sea-salt aerosol, the aqueous phase reaction of DMSO with $\mathrm{OH}$ is still of comparable importance with the gas phase reaction. When leaving the marine boundary layer to the buffer layer, it is likely that the oxidation of DMSO would be very different. That is confirmed by field observations made by Davis et al. [1998] at Palmer showing a rapid increase of the DMSO mixing ratio (up to $20 \mathrm{pptv}$ instead of $2 \mathrm{pptv}$ ) when rapid vertical transport brought buffer layer air mass within the boundary layer. These observations imply a longer lifetime of DMSO in the buffer layer than in the boundary layer, following a strong weakening of the heterogeneous reaction of DMSO caused by a far lower aerosol surface (and liquid water) available there. In our calculations we have therefore assumed that the heterogeneous chemistry of DMSO becomes negligible with respect to the gas phase chemistry in the buffer layer.

[26] In the buffer layer DMSO is oxidized by $\mathrm{OH}$ in the gas phase to produce either methane sulfonic acid (hereafter denoted MSA) or $\mathrm{SO}_{2}$. The branching ratios between the two pathways ( $\beta_{3}$ and $\beta_{4}$, Figure 5$)$ are not precisely known yet. At $298 \mathrm{~K}, \mathrm{SO}_{2}$ seems to be the major product of the gas phase oxidation of DMSO via the intermediate production of methane sulfinic acid (MSIA) [Arsene et al., 2002; Kukui et al., 2003]. Arsene et al. [1999] determined the initial branching ratios of the DMS oxidation between the addition and the abstraction pathways and the overall production of $\mathrm{SO}_{2}$ via the two pathways for 3 different temperatures, respectively. Referring to Davis et al. [1998] who showed that in the addition pathway $\mathrm{SO}_{2}$ is not directly produced but produced from DMSO, we can postulate that $\mathrm{SO}_{2}$ observed by Arsene et al. [1999] comes from the DMSO oxidation (i.e., $\beta_{1}=1$ and $\beta_{2}=0$, Figure 5) and therefore calculate this production via $\beta_{4}$. Following Arsene et al. [1999], $\mathrm{SO}_{2}$ is, at Antarctic temperatures, the main product of the DMSO $+\mathrm{OH}$ reaction $\left(\beta_{3}=0\right.$ below $239 \mathrm{~K}$, see Figure 5 and Table 2). Finally, $\mathrm{SO}_{2}$ is converted into sulfuric acid in the gas phase by $\mathrm{OH}$.

\subsection{Results and Discussions}

[27] Photochemical calculations have been performed for two time periods in 2006: from 26 January to 2 February 
Table 3. Summary of Calculations Made for the Chemical Composition of the Buffer Layer Inland Antarctica Following a DMS Injection $^{\mathrm{a}}$

\begin{tabular}{|c|c|c|c|c|}
\hline & \multicolumn{2}{|c|}{26 January to 2 February } & \multicolumn{2}{|c|}{11 to 18 March } \\
\hline & \multicolumn{4}{|c|}{ Input Parameters } \\
\hline DMS (pptv) & \multirow{4}{*}{\multicolumn{2}{|c|}{$\begin{array}{c}100 \\
4.0 \times 10^{5} \\
243-253 \mathrm{~K} \\
640 \mathrm{mbar}\end{array}$}} & \\
\hline $\mathrm{OH}\left(\text { molecule } \mathrm{cm}^{-3}\right)^{\mathrm{c}}$ & & & & \\
\hline Temperature range & & & & \\
\hline Pressure & & & & \\
\hline \multirow[t]{2}{*}{$\mathrm{BrO}$ (molecule $\mathrm{cm}^{-3}$ ) } & 0 & $2.5 \times 10^{7}$ & 0 & $2.5 \times 10^{7}$ \\
\hline & \multicolumn{4}{|c|}{ Mixing Ratios After 5 Days } \\
\hline DMS (pptv) & $0.8-2.1$ & $0.00-0.01$ & $8.4-10$ & $0.00-0.01$ \\
\hline $\mathrm{SO}_{2}$ (pptv) & $80-71$ & $82-72$ & $47-43$ & $57-49$ \\
\hline $\mathrm{MS}^{-}$(pptv) & $4.5-14$ & $5-16$ & $0-2$ & $0-3$ \\
\hline \multirow[t]{2}{*}{ Sulfate (pptv) } & $12-9$ & $13-11$ & $2-1.7$ & $3.3-2.8$ \\
\hline & \multicolumn{4}{|c|}{ Mixing Ratios After 10 Days } \\
\hline DMS (pptv) & $0.01-0.04$ & $0.00-0.00$ & $1.2-1.6$ & $0.00-0.00$ \\
\hline $\mathrm{SO}_{2}$ (pptv) & $68-62$ & $68-61$ & $51.6-49$ & $53-50$ \\
\hline $\mathrm{MS}^{-}$(pptv) & $4.5-14.3$ & $5.0-16.4$ & $0-2.6$ & $0-3$ \\
\hline Sulfate (pptv) & $25-21$ & $27-22$ & $5.7-4.9$ & $7.3-6.4$ \\
\hline
\end{tabular}

when low $\mathrm{MS}^{-}$levels were recorded at Concordia, from 11 to 18 March when $\mathrm{MS}^{-}$levels reached their maximum. Calculations were made at 640 mbar (i.e., $\sim 3000 \mathrm{~m}$ ), at $243-253 \mathrm{~K}$ in January and at 233-243 K in March. Results of calculations made by considering only the gas phase chemistry and a single DMS injection in the buffer layer are reported in Table 3 . Since, in the atmosphere sulfuric acid and MSA are rapidly lost on aerosol, the values are reported as sulfate and $\mathrm{MS}^{-}$equivalent, respectively. Whatever the time period, after 10 days, DMS is efficiently oxidized by $\mathrm{OH}$ in the buffer layer and $\mathrm{SO}_{2}$ is the main byproduct via the oxidation of DMSO.

[28] In March the gas phase $\mathrm{OH}$ oxidation of $\mathrm{SO}_{2}$ formed 5.5 pptv of sulfate (i.e., $0.24 \mathrm{nmol} \mathrm{m}^{-3}$ ) and $1.5 \mathrm{pptv}$ (i.e., $0.06 \mathrm{nmol} \mathrm{m}^{-3}$ ) of $\mathrm{MS}^{-}$. As seen in Table 4 , the $\mathrm{MS}^{-}$to $\mathrm{nss}_{4} \mathrm{SO}_{4}^{2-}$ ratio (r) calculated in the buffer layer $(0.25)$ is lower than the one measured in the marine boundary layer (0.46). Mixing between the boundary layer and the buffer layer would lead to a sulfur aerosol with an intermediate $r$ value (between 0.25 and 0.4 ). Subsequently, during the inland transport at higher altitudes, the $\mathrm{r}$ signature may change due to the presence of $\mathrm{SO}_{2}$. In fact $\mathrm{SO}_{2}$ is present in the boundary layer/buffer layer air parcel as well as above, since the buffer layer is turbulent. However, the presence of $\mathrm{SO}_{2}$ would not modify the $\mathrm{r}$ value since the oxidation of $\mathrm{SO}_{2}$ into sulfuric acid is very slow at that time of the year. Note that the lifetime of $\mathrm{SO}_{2}$ with respect to its gas phase oxidation is as long as 70 days at the coast and 150 days over the high plateau in March.

[29] In January, $1 \mathrm{nmol} \mathrm{m}^{-3}$ of sulfate and $0.4 \mathrm{nmol} \mathrm{m}^{-3}$ of $\mathrm{MS}^{-}$are formed after 10 days by the gas phase oxidation of $\mathrm{SO}_{2}$. The r value calculated in the buffer layer $(0.40)$ is as high as that measured in MBL (0.46). Note that this does not conflict with the above discussed preferential oxidation pathways toward $\mathrm{SO}_{2}$ in the buffer layer. In fact, as discussed by Davis et al. [1998], parcels of buffer layer are episodically entrained back into the boundary layer, and this subsequent injection of $\mathrm{SO}_{2}$ will largely control the sulfate level in the boundary layer. Without this downward trans- port, we would expect far higher $r$ values in the boundary layer. In contrast to the situation in March, the $r$ signature will significantly change during the inland transport at higher altitude, since once having reached $1500 \mathrm{~m}$ elevation, the $\mathrm{SO}_{2}$ present in the parcel continues to efficiently produce sulfate via sulfuric acid. Indeed, the air parcel will experience very oxidative conditions over the plateau. For instance, referring to a typical daily mean $\mathrm{OH}$ concentration of $3 \times 10^{6}$ radicals $\mathrm{cm}^{-3}$ observed by Mauldin et al. [2004] at the South Pole in the inversion layer, the lifetime of $\mathrm{SO}_{2}$ would not exceed 4 days with respect to its gas phase oxidation into sulfuric acid. The efficiency of the oxidation of $\mathrm{SO}_{2}$ in air masses traveling over the Antarctic plateau is corroborated by the study of Huey et al. [2004]. On the basis of observed gaseous level of sulfuric acid at the South Pole end of December, Huey et al. [2004] estimated that the level of $\mathrm{SO}_{2}$ would not exceed $1.4 \mathrm{pptv}$. Therefore we can assume that during the travel over inland Antarctica the entire amount of $\mathrm{SO}_{2}$ has been converted into sulfuric acid. Considering this effect the r value initially close to $40 \%$ would drop to $10 \%$ when the air mass reaches the high plateau.

[30] In Table 3 we also report calculation outcomes considering a $\mathrm{BrO}$ level of 1 pptv. It could be seen that DMS and DMSO are destroyed and produced more efficiently, respectively. Aside these differences the relative contribution of $\mathrm{MS}^{-}$and sulfate remains basically un-

Table 4. Comparison of the Composition of the Marine Boundary Layer at DDU and the Simulated Chemical Composition of the Buffer Layer Following a 100 pptv DMS Injection (As Reported in Table 3)

\begin{tabular}{llcc}
\hline & & $\begin{array}{c}\text { Boundary Layer } \\
\left(\mathrm{nmol} \mathrm{m}^{-3}\right)\end{array}$ & $\begin{array}{c}\text { Buffer Layer } \\
\left(\mathrm{nmol} \mathrm{m}^{-3}\right)\end{array}$ \\
\hline End of January & $\mathrm{nssSO}_{4}{ }^{2-}$ & 2.2 & 1 \\
& $\mathrm{MS}^{-}$ & 0.6 & 0.4 \\
Mid-March & $\mathrm{r}$ & $27 \%$ & $40 \%$ \\
& $\mathrm{nsSSO}_{4}{ }^{2-}$ & 0.75 & 0.24 \\
& $\mathrm{MS}^{-}$ & 0.35 & 0.06 \\
& $\mathrm{r}$ & $46 \%$ & $25 \%$ \\
\hline
\end{tabular}


changed with respect to conditions for which only the $\mathrm{OH}$ photochemistry of DMS is considered.

[31] In conclusion, the different seasonal cycles of $\mathrm{MS}^{-}$ and sulfate observed at coastal and inland Antarctic sites may be originating from: (1) the weakened input of sulfur aerosols advected from the marine area (boundary layer and buffer layer) in January with respect to March (see section 6) in conjunction with (2) a DMS photochemistry, by $\mathrm{OH}$ alone as well as by $\mathrm{OH}$ and $\mathrm{BrO}$, favoring the formation of $\mathrm{SO}_{2}$ (and its subsequent oxidation into sulfuric acid) with respect to the one of MSA during the travel inland Antarctica.

\section{Implications for Interpretation of MSA and Sulfate Signal in Ice Cores}

[32] Even in regions not impacted by anthropogenic $\mathrm{SO}_{2}$ emission, non-sea-salt sulfate may have several sources including marine biogenic, terrestrial, and volcanic sources while $\mathrm{MS}^{-}$is exclusively formed by oxidation of DMS emitted by algae. That stimulated the pioneer studies of $\mathrm{MS}^{-}$in Antarctic ice cores [Saigne and Legrand, 1987] to trace back past biogenic marine emissions. Focusing on Holocene ice core records, one of the striking finding was the low values of $r$ in central Antarctic snow (5-20\%) that contrasts with higher values seen in coastal snow $(25-35 \%)$ [Legrand et al., 1992]. Previous explanations for these spatial changes of $r$ values in the literature invoked a shorter atmospheric lifetime of $\mathrm{MS}^{-}$aerosol with respect to sulfate one, due to a larger size of $\mathrm{MS}^{-}$aerosol with respect to that of nss $\mathrm{SO}_{4}^{2-}$. However, size-segregated aerosol composition studies performed at the coastal site of DDU as well as at Concordia do not evidenced such a difference between $\mathrm{MS}^{-}$ and $\mathrm{nsSSO}_{4}^{2-}$, both present in particle size of $\sim 0.3 \mu \mathrm{m}$ [Jourdain et al., 2008]. A more recent hypothesis to explain this coastal-inland difference suggested postdepositional loss of $\mathrm{MS}^{-}$at inland sites characterized by low snow accumulation rates [Wagnon et al., 1999]. Our atmospheric data indicated an average $r$ value at Concordia of $17 \%$ from October to March instead of $30 \%$ at DDU. Only from March to October/November the $r$ ratios are similar at the two sites. Thus, at least a part of the observed decrease of $r$ values from coastal to inland snow deposits is linked to the seasonal different atmospheric composition of sulfur aerosol.

[33] Preunkert et al. [2007] have shown that at coastal Antarctic sites $\mathrm{MS}^{-}$covaries well with DMS emissions from south of $62^{\circ} \mathrm{S}$ while sulfate corresponds to DMS emissions from a broader scale (up to $58^{\circ} \mathrm{S}$ ). Therefore, and thought that postdepositional effects are not efficient at coastal sites, we may expect good records of high southern marine biota in coastal ice cores. On the other hand, the relation between inland $\mathrm{MS}^{-}$ice records and DMS emissions appears far poorer than previously hypothesized since postdeposition loss of $\mathrm{MS}^{-}$act significantly at sites where snow accumulation rate are lower than $100 \mathrm{~kg} \mathrm{~m}^{2} \mathrm{a}^{-1}$ [Weller et al., 2004]. This effect is likely a key process at Concordia given the very low snow accumulation rate permitting a long time aging of fresh surface snow $\left(20-30 \mathrm{~kg} \mathrm{~m}^{2} \mathrm{a}^{-1}\right)$ but the involved process are not yet elucidated (photochemical destruction of $\mathrm{MS}^{-}$within the firn layers or/and reemission of MSA from the firn layers to the atmosphere). Anyway the poor correlation between atmospheric $\mathrm{MS}^{-}$and $\mathrm{nssSO}_{4}^{2-}$ levels over the course of spring-summer-fall, as a result of a different chemistry over marine and inland regions, also greatly complicates the relationship between $\mathrm{MS}^{-}$and its gaseous DMS precursor. Since sulfur isotopic studies have shown that except for sporadic volcanic input, sulfate is mainly biogenic in origin [Patris et al., 2000]; sulfate thus appears to be the best tracer of marine DMS emissions of the austral ocean under present-day atmospheric conditions. It remains still difficult to extrapolate this statement for glacial climate conditions. For example, the atmospheric meaning of sulfur ice core records that have shown large increase of $\mathrm{MS}^{-}$but not of $\mathrm{nssSO}_{4}^{2-}$ during ice ages compared to present-day climate [Legrand et al., 1991] remain unclear. Several factors may have contributed to these differences including enhanced marine DMS emissions, more limited lost of $\mathrm{MS}^{-}$or far more efficient heterogeneous chemistry acting in the buffer layer leading to a faster production of MSA than the one of $\mathrm{SO}_{2}$ from DMSO due to the large increase of dust and sea salt during the ice age.

[34] Acknowledgments. National financial support and field logistic supply for over winter and summer campaigns at Concordia and DDU were provided by Institut Paul Emile Victor (IPEV) within the French programs 903 and 414 and Italian PNRA. This work was also partly funded by the Centre National de la Recherche Scientifique (CNRSINSU) within the program LEFE-CHAT. We would like to greatly thank Yvan Lévy who performed the DMS measurements during winter at the Concordia station and to the VCAT of program IPEV-414, especially Sylvain Masclin, Aouregan Terre-Terrillon, Lucie Jorge, and Thomas Romero for DDU samplings and analyses. We would like to acknowledge the three anonymous reviewers for their helpful comments. The authors gratefully acknowledge the Air Resources Laboratory (ARL) for the provision of the HYSPLIT transport and dispersion model on the READY Web site (http://www.arl.noaa.gov/ready.html) used in this publication.

\section{References}

Arimoto, R., A. S. Nottingham, J. Webb, C. A. Schloesslin, and D. D. Davis (2001), Non-sea-salt sulfate and other aerosol constituents at the South Pole during ISCAT, Geophys. Res. Lett., 28(19), 3645-3648, doi:10.1029/2000GL012714.

Arimoto, R., A. Hogan, P. Grube, D. Davis, J. Webb, C. Schloesslina, S. Sagea, and F. Raccah (2004), Major ions and radionuclides in aerosol particles from the South Pole during ISCAT-2000, Atmos. Environ., 38 , 5473-5484, doi:10.1016/j.atmosenv.2004.01.049.

Arsene, C., I. Barnes, and K. H. Becker (1999), FT-IR product study of the photo-oxidation of dimethyl sulfide: Temperature and $\mathrm{O}_{2}$ partial pressure dependence, Phys. Chem. Chem. Phys., 1, 5463-5470, doi:10.1039/a907211j. Arsene, C., I. Barnes, K. H. Becker, W. F. Schneider, T. T. Wallington, N. Mihalopoulos, and I. V. Patroescu-Klotz (2002), Formation of methane sulfinic acid in the gas-phase $\mathrm{OH}$-radical initiated oxidation of dimethyl sulfoxide, Environ. Sci. Technol., 36(23), 5155-5163, doi:10.1021/es020035u.

Bardouki, H., M. Barcellos da Rosa, N. Mihalopoulos, W.-U. Palm, and C. Zetzsch (2002), Kinetics and mechanism of the oxidation of dimethylsulfoxide (DMSO) and methanesulfinate (MSI-) by OH radicals in aqueous medium, Atmos. Environ., 36, 4627-4634, doi:10.1016/S13522310(02)00460-0

Barnes, I., J. Hjorth, and N. Mihalopoulos (2006), Dimethyl sulphide and dimethyl sulfoxide and their oxidation in the atmosphere, Chem. Rev, 106, 940-975, doi:10.1021/cr020529+.

Bloss, W. J., J. D. Lee, D. E. Heard, R. A. Salmon, S.-J.-B. Bauguitte, H. K. Roscoe, and A. E. Jones (2007), Observations of $\mathrm{OH}$ and $\mathrm{HO}_{2}$ radicals in coastal Antarctica, Atmos. Chem. Phys., 7, 4171-4185.

Curran, M. A. J., T. D. Van Ommen, V. I. Morgan, K. L. Phillips, and A. S. Palmer (2003), Ice core evidence for Antarctic sea ice decline since 1950s, Science, 302, 1203-1206, doi:10.1126/science.1087888.

Davis, D. D., G. Chen, P. Kasibhatla, A. Jefferson, D. Tanner, F. Eisele, D. Lenschow, W. Neff, and H. Berresheim (1998), DMS oxidation in the Antarctic marine boundary layer: Comparison of model simulations and field observations of DMS, DMSO, DMSO $, \mathrm{H}_{2} \mathrm{SO}_{4}(\mathrm{~g}), \mathrm{MSA}(\mathrm{g})$, and MSA(p), J. Geophys. Res., 103, 1657-1678, doi:10.1029/ 97JD03452. 
Davis, D. D., et al. (2004), An overview of ISCAT 2000, Atmos. Environ., 38, 5363-5373, doi:10.1016/j.atmosenv.2004.05.037.

de Mora, S. J., D. J. Wylie, and A. L. Dick (1997), Methanesulphonate and non-sea salt sulfate in aerosol, snow and ice on the east Antarctic plateau, Antarct. Sci., 9(1), 46-55, doi:10.1017/S0954102097000072.

Frieß, U., J. Hollwedel, G. König-Langlo, T. Wagner, and U. Platt (2004), Dynamics and chemistry of tropospheric bromine explosion events in the Antarctic coastal regions, J. Geophys. Res., 109, D06305, doi:10.1029/ 2003JD004133.

Gondwe, M., M. Krol, W. Gieskes, W. Klaassen, and H. de Baar (2003), The contribution of ocean-leaving DMS to the global atmospheric burdens of DMS, MSA, $\mathrm{SO}_{2}$, and $\mathrm{NSS} \mathrm{SO}_{4}^{2-}$, Global Biogeochem. Cycles, 17(2), 1056, doi:10.1029/2002GB001937.

Harder, S., S. G. Warren, and R. J. Charlson (2000), Sulfate in air and snow at the South Pole: Implications for transport and deposition at sites with low snow accumulation, J. Geophys. Res., 105, 22,825-22,832, doi:10.1029/2000JD900351.

Herrmann, H., B. Ervens, H.-W. Jacobi, R. Wolke, P. Novaki, and R. Zellner (2000), CAPRAM2.3: A chemical aqueous phase radical mechanism for tropospheric chemistry, J. Atmos. Chem., 36, 231-284, doi:10.1023/ A: 1006318622743.

Huey, L. G., et al. (2004), CIMS measurements of $\mathrm{HNO}_{3}$ and $\mathrm{SO}_{2}$ at the South Pole during ISCATE 2000, Atmos. Environ., 38, 5411-5421, doi:10.1016/j.atmosenv.2004.04.037.

Jefferson, A., D. J. Taner, F. L. Eisele, D. D. Davis, G. Chen, J. Crawford, J. W. Huey, A. L. Torres, and H. Berresheim (1998), OH photochemistry and methane sulfonic acid formation in the coastal Antarctic boundary layer, J. Geophys. Res., 103, 1647-1656, doi:10.1029/97JD02376.

Jones, A. E., et al. (2007), The multi-seasonal NOy budget in coastal Antarctica and its link with surface snow and ice core nitrate: Results from the CHABLIS campaign, Atmos. Chem. Phys. Discuss., 7, 4127-4163.

Jourdain, B., and M. Legrand (2001), Seasonal variations of dimethyl sulfide, dimethyl sulfoxide, sulfur dioxide, methanesulfonate, and non-seasalt sulfate aerosols at Dumont d'Urville (December 1998-July 1999), J. Geophys. Res., 106, 14,391-14,408, doi:10.1029/2000JD900841.

Jourdain, B., and M. Legrand (2002), Year-round records of bulk and sizesegregated aerosol composition and $\mathrm{HCl}$ and $\mathrm{HNO}_{3}$ levels in the Dumont d'Urville (coastal Antarctica) atmosphere: Implications for sea-salt aerosol in the winter and summer, J. Geophys. Res., 107(D22), 4645, doi:10.1029/2002JD002471.

Jourdain, B., S. Preunkert, O. Cerri, H. Castebrunet, R. Udisti, and M. Legrand (2008), Year round record of size-segregated aerosol composition in central Antarctica (Concordia station): Implications for the degree of fractionation of sea-salt particles, J. Geophys. Res., doi:10.1029/2007JD009584, in press.

Katoshevski, D., A. Nenes, and J. H. Seinfeld (1999), A study of processes that govern the maintenance of aerosols in the marine boundary layer, J. Aerosol Sci., 30, 503-532, doi:10.1016/S0021-8502(98)00740-X.

Kukui, A., D. Borissenko, G. Laverdet, and G. LeBras (2003), Gas-Phase reactions of $\mathrm{OH}$ radicals with dimethyl sulfoxide and methane sulfinic acid using turbulent flow reactor and chemical ionization mass spectrometry, J. Phys. Chem. A, 107, 5732-5742, doi:10.1021/jp0276911.

Legrand, M., and C. Feniet-Saigne (1991), Methanesulfonic acid in south polar snow layer: A record of strong El Nino, Geophys. Res. Lett., 18 187-190, doi:10.1029/90GL02784.

Legrand, M., and P. Mayewski (1997), Glaciochemistry of polar ice cores: A review, Rev. Geophys., 35, 219-243, doi:10.1029/96RG03527.

Legrand, M., C. Feniet-Saigne, E. S. Saltzman, C. Germain, N. I. Barkov, and V. N. Petrov (1991), An ice core record of oceanic emissions of dimethylsulfide during the last climatic cycle, Nature, 350, 144-146, doi:10.1038/350144a0.

Legrand, M., C. Feniet-Saigne, E. S. Saltzman, and C. Germain (1992), Spatial and temporal variations of methanesulfonic acid and non sea salt sulfate in Antarctic ice, J. Atmos. Chem., 14, 245-260, doi:10.1007/ BF00115237.

Legrand, M., J. Sciare, B. Jourdain, and C. Genthon (2001), Daily variations of dimethyl sulfide, dimethyl sulfoxide, methanesulfonate, and nonsea-salt sulfate aerosols at Dumont d'Urville (December 1998-March 1999), J. Geophys. Res., 106, 14,409-14,422, doi:10.1029/ 2000JD900840.

Mauldin, R. L., III, et al. (2004), Measurements of $\mathrm{OH}, \mathrm{HO}_{2}+\mathrm{RO}_{2}$, $\mathrm{H}_{2} \mathrm{SO}_{4}$, and MSA at the South Pole during ISCAT 2000, Atmos. Environ. 38, 5423-5437, doi:10.1016/j.atmosenv.2004.06.031.

Minikin, A., M. Legrand, J. Hall, D. Wagenbach, C. Kleefeld, E. Wolff, E. C. Pasteur, and F. Ducroz (1998), Sulfur-containing species (sulfate and methanesulfonate) in coastal Antarctic aerosol and precipitation, J. Geophys. Res., 103, 10,975-10,990, doi:10.1029/98JD00249.

Patris, N., R. J. Delmas, and J. Jouzel (2000), Isotopic signatures of sulfur in shallow Antarctic ice cores, J. Geophys. Res., 105, 7071-7078, doi:10.1029/1999JD900974.

Pham, M., J. F. Muller, G. Brasseur, C. Granier, and G. Mégie (1995), A three-dimensional study of tropospheric sulfur cycle, J. Geophys. Res., 100, 26,061-26,092, doi:10.1029/95JD02095.

Piel, C., R. Weller, M. Huke, and D. Wagenbach (2006), Atmospheric methane sulfonate and non-sea salt sulphate records at the EPICA deep-drilling site in Dronning Maud Land, Antarctica, J. Geophys. Res., 111, D03304, doi:10.1029/2005JD006213.

Preunkert, S., M. Legrand, B. Jourdain, C. Moulin, S. Belviso, N. Kasamatsu, M. Fukuchi, and T. Hirawake (2007), Interannual variability of dimethylsulfide in air and seawater and its atmospheric oxidation by-products (methanesulfonate and sulfate) at Dumont d'Urville, coastal Antarctica (1999-2003), J. Geophys. Res., 112, D06306, doi:10.1029/ 2006JD007585.

Read, K. A., et al. (2008), DMS and MSA measurements in the Antarctic boundary layer: Impact of BrO on MSA production, Atmos. Chem. Phys. Discuss., 8, 2657-2694.

Saigne, C., and M. Legrand (1987), Measurements of methanesulphonic acid in Antarctic ice, Nature, 330, 240-242, doi:10.1038/330240a0.

Saiz-Lopez, A., A. S. Mahajan, R. A. Salmon, S.-J.-B. Bauguitte, A. E. Jones, H. K. Roscoe, and J. M. C. Plane (2007), Boundary layer halogens in coastal Antarctica, Science, 317, 348-351, doi:10.1126/science.1141408.

Sciare, J., M. Kanakidou, and N. Mihalopoulos (2000), Diurnal and seasonal variation of atmospheric dimethylsulfoxide (DMSO) at Amsterdam Island in the southern Indian Ocean, J. Geophys. Res., 105, 17,25717,266, doi:10.1029/1999JD901186.

Seinfeld, J. H., and S. Pandis (1998), Atmospheric Chemistry and Physics: From Air Pollution to Climate, 1326 pp., John Wiley, Hoboken, N. J.

Simpson, W. R., et al. (2007), Halogens and their role in polar boundarylayer ozone depletion, Atmos. Chem. Phys., 7, 4375-4418.

Swanson, A. L., et al. (2004), Organic trace gases of oceanic origin observed at South Pole during ISCAT 2000, Atmos. Environ., 38, $5463-$ 5472, doi:10.1016/j.atmosenv.2004.03.072.

Udisti, R., S. Becagli, S. Benassai, E. Castellano, I. Fattori, M. Innocenti, A. Migliori, and R. Traversi (2004), Atmosphere-snow interaction by a comparison between aerosol and uppermost snow layers composition at Dome C (East Antarctica), Ann. Glaciol., 39, 53-61, doi:10.3189/ 172756404781814474

Wagenbach, D., F. Ducroz, R. Mulvaney, L. Keck, A. Minikin, M. Legrand, J. Hall, and E. Wolff (1998), Sea salt aerosol in coastal Antarctic regions, J. Geophys. Res., 103, 10,961-10,974, doi:10.1029/97JD01804.

Wagner, T., O. Ibrahim, R. Sinreich, U. Frieß, R. von Glasow, and U. Platt (2007), Enhanced tropospheric BrO over Antarctic sea ice in mid winter observed by MAX-DOAS on board the research vessel Polarstern, Atmos. Chem. Phys., 7, 3129-3142.

Wagnon, P., R. Delmas, and M. Legrand (1999), Loss of volatile acid species from upper firn layers at Vostok, J. Geophys. Res., 104, $3423-$ 3431, doi:10.1029/98JD02855.

Welch, K. A., P. A. Mayewski, and S. I. Whitlow (1993), Methanesulfonic acid in coastal Antarctic snow related to sea-ice extent, Geophys. Res. Lett., 20, 443-446, doi:10.1029/93GL00499.

Weller, R., and D. Wagenbach (2007), Year-round chemical aerosol records in continental Antarctica obtained by automatic sampling, Tellus, Ser. B, $59,755-765$.

Weller, R., F. Traufetter, H. Fischer, H. Oerter, C. Piel, and H. Miller (2004), post depositional losses of methane sulfonate, nitrate, and chloride at the EPICA deep-drilling site in Droning Maud land, Antarctica, J. Geophys. Res., 109, D07301, doi:10.1029/2003JD004189.

Zhu, L., J. M. Nicovich, and P. Wine (2003), Temperature-dependent kinetics studies of aqueous phase reactions of hydroxyl radicals with dimethylsulfoxide, dimethylsulfone, and methanesulfonate, Aquat. Sci., 65, 425-435, doi:10.1007/s00027-003-0673-6.

S. Becagli, O. Cerri, and R. Udisti, Department of Chemistry, University of Florence, I-50121 Florence, Italy.

B. Jourdain, M. Legrand, and S. Preunkert, Laboratoire de Glaciologie et Géophysique de l'Environnement du Centre National de la Recherche Scientifique, F-38042 St. Martin d'Hères, France. (preunkert@1gge.obs. ujf-grenoble.fr) 